\title{
PENENTUAN HARGA JUAL PRODUK HASIL KETERAMPILAN HANDYCRAFT DALAM MENINGKATKAN INDUSTRI KREATIF UNTUK KELOMPOK PKK KELURAHAN BALEKAMBANG JAKARTA TIMUR
}

\author{
Kanaria Herwati, Rudeva Juniawaty, dan Siti Juriah \\ Pendidikan Ekonomi, Fakultas Pendidikan dan Ilmu Sosial \\ Universitas Indraprasta PGRI Jakarta \\ kanaria_smart@yahoo.com; eva_rj@yahoo.com; sitijuriah336@gmail.com
}

\begin{abstract}
Abstrak
Kegiatan Pengabdian Masyarakat ini bertujuan untuk memberikan pelatihan keterampilan pembuatan handycrafts dan penentuan harga jual produk dalam meningkatkan industri kreatif pada kelompok PKK RW 03 dan RW 04 Keurahan Balekambang Kecamatan Kramat Jati Jakarta Timur. Target rencana kegiatan ini adalah salah satu dari Tri Dharma Perguruan Tinggi yaitu Pengabdian Kepada Masyarakat. Metode yang digunakan oleh Tim Dosen Universitas Indraprasta PGRI dalam kegiatan pengabdian masyarakat ini adalah dengan memberikan pelatihan pembuatan kerajinan tangan dengan menggunakan barang bekas berupa kain perca tile dan aplikasi kain pita kepada 30 (tiga puluh) ibu-ibu yang tergabung dalam kelompok PKK di Rw. 03 dan Rw. 04 Condet Balekambang, Kramat Jati, Jakarta Timur. Adapun bentuk produk yang akan dihasilkan berupa bross bunga kuncup dan mekar, bando, dan hiasan jilbab dengan memanfaatkan limbah berupa kain perca tile dan pita.
\end{abstract}

Kata kunci: kain perca, kerajinan tangan, harga jual

\begin{abstract}
These Outreach activities aim to provide skills training making handycrafts and determining the selling price of the product in improving creative industries group PKK RW 03 and RW 04 Keurahan Balekambang Subdistrict Kramat Jati East Jakarta. The target plan this activity is one of the Tri Dharma Universities i.e. Community.The methods used by a team of University Professors IndraprastaPGRI in this outreach activity is to provide training in making handicrafts using the thrift in the form of patchwork fabric ribbons and tile applications to 30 (thirty) mothers who are members of the Group of PKK in Rw. 03 and Rw. 04 Condet Balekambang, Kramat Jati, East Jakarta as for the shape of the product to be produced in the form of floral buds and blooms bross, bando, and ornate veil by utilizing waste cloths patchwork tile and Ribbon.
\end{abstract}

Keywords: patchwork, handicrafts, sale price

\section{PENDAHULUAN}

\section{Analisis Situasi}

Angka pengangguran di Indonesia per Februari 2017 tercatat mencapai 7,01 juta jiwa. Dengan tingkat pengangguran terbuka tercatat sebesar 5,50\%. Porsi paling besar dari pengangguran ada di perkotaan dengan $6,5 \%$, sedangkan desa 4\%. Angka yang bukan angkatan kerja mencapai 59,04 juta. Bukan angkatan kerja ini termasuk di dalamnya adalah ibu rumah tangga. (https://finance.detik.com) 
Menurut Sukirno (2004: 28), pengangguran adalah jumlah tenaga kerja dalam perekonomian yang secara aktif mencari pekerjaan tetapi belum memperolehnya. Menurut Sinclair 1987; Kuruvilla 1995 (dalam Benson dan Zhu $:$ : 18) unemployment represents a severe loss of skills and productive capacity from society.

Salah satu cara untuk menanggulangi pengangguran adalah dengan dijalankannya industri kreatif, hal ini disampaikan oleh Kementerian Tenaga Kerja dan Transmigrasi (Kemenakertrans) bahwa sektor industri kreatif terbukti mampu mengurangi pengangguran dan meningkatkan perekonomian negara. Hal ini dibuktikan dengan pertumbuhan ekonomi Indonesia menjadi 5.0 persen pada tahun 2016 dari 4,9 persen pada 2015, walaupun ketidakpastian kebijakan global masih tinggi. (http://www.worldbank.org).

Untuk terus menjaga kelangsungan usaha dari para pelaku industri kreatif, Kemenakertrans melakukan pelatihan, pengkaderan, perintisan, pendampingan, pembinaan dan pengembangan usaha untuk lebih maju. Industri kreatif merupakan industri yang berasal dari pemanfaatan kreativitas, ketrampilan serta bakat individu untuk menciptakan kesejahteraan serta lapangan pekerjaan dengan menghasilkan dan mengeksploitasi daya kreasi dan daya cipta individu tersebut. Dalam mengembangkan industri kreatif, kreativitas dan inovasi sangat diperlukan untuk keberhasilan usaha. Kreativitas adalah kemampuan untuk mengembangkan ideide baru dan cara-cara baru dalam pemecahan masalah dan menemukan peluang. Jadi, kreativitas adalah kemampuan untuk memikirkan sesuatu yang baru dan berbeda (Suryana 2003:2).

Seperti yang telah dijelaskan di atas, bahwa pengangguran yang bukan dari angkatan kerja mencapai 59,04 juta dan yang termasuk di dalamnya adalah ibu rumah tangga. Maka kami sebagai tim pelaksana pengabdian masyarakat melirik kelompok PKK di Kelurahan Balekambang, yang berisikan ibu - ibu rumah tangga. Salah satu alasan pemilihan lokasi didasarkan pada letak Kelurahan Balekambang yang hanya berjarak 2,5 $\mathrm{km}$ dari Universitas Indraprasta PGRI Kampus B. Kelurahan Balekambang sendiri terdiri dari $5 \mathrm{RW}$, dengan 53 RT. Kelima RW tersebut memiliki kelompok PKK dan terdapat aktivitas setiap minggunya. Melihat keaktifan dari kelompok PKK tersebut maka tim pelaksana pengabdian terhadap masyarakat berusaha untuk memberikan pelatihan untuk menambah kreativitas kelompok tersebut.

Hal lainnya yang mendasari pemilihan kelompok PKK adalah wawancara dengan Kepala Kelurahan Balekambang yang menyatakan bahwa sampai dengan saat ini belum terdapat UMKM binaan Kelurahan, hal ini dikarenakan wilayah Kelurahan Balekambang yang masih merupakan perkampungan padat penduduk (wawancara tanggal 5 September 2017). Namun kami berpikir tidak menutup kemungkinan bahwa dari kelompok PKK yang sangat aktif tersebut muncul UMKM baru.

Melihat keaktifan dan potensi dari kelompok PKK di lingkungan Kelurahan Balekambang, khususnya PKK RW 03 dan 04, maka tim pelaksana pengabdian masyarakat tertarik untuk memberikan pelatihan keterampilan pembuatan handycrafts dan penentuan harga jual produk dalam meningkatkan industri kreatif.

\section{Permasalahan Mitra}

Perguruan tinggi Unindra merupakan bagian dari lingkungan di masyarakat yang menyadari akan peran penting untuk berkontribusi meningkat- 
kan kesejahteraan sosial masyarakat. Melalui mitra kelompok ibu-ibu PKK di tingkat kelurahan, tim dari Unindra berusaha menjawab permasalahan yang dihadapi oleh kelompok PKK di antaranya adalah :

1. Pelatihan kerajinan tangan masih kurang

2. Penentuan harga jual produk yang diketahui hanya yang bersifat tradisional

3. Kurangnya pengetahuan mengenai media pemasaran

Sebelum menjalin mitra dengan Kelompok PKK Kelurahan Balekambang, tim abdimas Unindra telah menghimpun informasi awal yang terkait dengan persoalan Kelompok PKK Kelurahan Balekambang. Datadata awal yang diperoleh oleh tim abdimas antara lain kurangnya kegiatankegiatan yang berkaitan dengan upaya pemberdayaan kelompok PKK untuk dapat meningkatkan kesejahteraan mereka melalui kegiatan yang bersifat produktif dan masih minimnya pengetahuan kelompok PKK dalam penentuan harga dan strategi pemasaran.

Berdasarkan informasi yang tim abdimas dapatkan, maka tim abdimas Unindra dari program studi Pendidikan Ekonomi merasa bertanggungjawab untuk bersama-sama mereka mengatasi persoalan peningkatan kapasitas dan kapabilitas kelompok PKK yang terhimpun dalam wadah PKK Kelurahan Balekambang, Kramat Jati dengan berusaha mencoba menjawab persoalanpersoalannya dalam menjalankan kegiatan usaha ekonomi produktif.

\section{Solusi yang Ditawarkan}

Dalam mengembangkan industri kreatif, kreativitas dan inovasi sangat diperlukan untuk keberhasilan usaha. Kreativitas adalah kemampuan untuk mengembangkan ide-ide baru dan caracara baru dalam pemecahan masalah dan menemukan peluang. Maka kami sebagai tim abdimas Unindra melirik kelompok PKK di Kelurahan Balekambang, yang berisikan ibu - ibu rumah tangga yang memiliki aktivitas setiap minggunya tetapi masih kurang berinovasi dan kurangnya kreativitas dalam menciptakan produk kerajinan. Melihat keaktifan dari kelompok PKK tersebut maka tim abdimas berusaha untuk memberikan pelatihan untuk menambah kreativitas kelompok tersebut.

Melihat keaktifan dan potensi dari kelompok PKK di lingkungan Kelurahan Balekambang tersebut, maka tim abdimas tertarik untuk memberikan pelatihan keterampilan pembuatan handycrafts dan penentuan harga jual produk dalam meningkatkan industri kreatif. Hal ini diharapkan dapat meningkatkan kreativitas dan inovasi dari kelompok ibu - ibu PKK tersebut. Sehingga ketika mereka akan membuat sebuah produk selain mampu membuatnya menjadi barang yang bernilai ekonomis, mereka juga mampu menentukan harga jual untuk produk tersebut.

\section{Tujuan Pengabdian Masyarakat}

Tujuan dari kegiatan pengabdian masyarakat ini adalah sebagai berikut :

1. Memberikan pelatihan kerajinan tangan menggunakan beberapa bahan alternatif.

2. Memberikan pelatihan cara perhitungan penentuan harga jual

3. Meningkatkan kreativitas dan inovasi dari kelompok PKK

\section{Target Pengabdian Masyarakat}

Peserta kegiatan ini adalah kelompok ibu - ibu PKK RW. 03 dan 04 Kelurahan Balekambang, Jakarta Timur. Maksud dan tujuan yang ingin diperoleh dari kegiatan ini di antaranya adalah : 
1. Meningkatkan kreativitas kelompok ibu - ibu PKK.

2. Mengembangkan kreativitas yang sudah ada.

3. Menemukan inovasi handycratfs baru

4. Dapat menentukan harga jual produk

\section{Luaran Pengabdian Masyarakat}

Luaran yang diharapkan melalui kegiatan penyuluhan ini adalah sebagai berikut :

1. Kelompok ibu - ibu PKK mampu membuat handycrafts yang memiliki nilai jual yang tinggi.

2. Menentukan laba yang diinginkan dan menghitung harga jual produk.

3. Menjadikan pelatihan keterampilan sebagai dasar untuk membangun industri kreatif yang dapat meningkatkan taraf kesejahteraan hidup bagi masyarakat sekitar.

4. Membuka lapangan pekerjaan baru bagi masyarakat sekitar.

5. Artikel jurnal metode pelaksanaan pelatihan pembuatan handycrafts dan penentuan harga jual produk, yang akan dikirimkan ke Jurnal Ekonomi Manajemen dan Akuntansi Universitas Serambi Mekkah, Aceh.

\section{METODE PELAKSANAAN}

\section{Perencanaan Materi}

Para peserta yang tergabung dalam Kelompok PKK Kelurahan Balekambang Kramat Jati akan diberikan materi pengetahuan mengenai bahan baku yang diperlukan dalam pembuatan handycraft seperti kain perca tile, kain pita, jarum, benang, lem tembak, dan lain-lain dan tim abdimas akan menjelaskan tahapan-tahapan pembuatan handycraft dengan memberikan contoh cara pembuatannya. Tim abdimas juga memberikan pengetahuan kepada peserta mengenai penentuan harga jual berdasarkan perhitungan biaya bahan baku.

\section{Waktu dan Tempat Pelaksanaan}

1. Waktu Pelaksanaan

Kegiatan pengabdian masyarakat ini dimulai dengan mengurus perizinan dan peninjauan daerah mitra yang dilakukan bulan September 2017. Pelaksanaan kegiatan pengabdian masyarakat dilakukan pada bulan Oktober dan November 2017.

2. Tempat Pelaksanaan

Tempat kegiatan pengabdian masyarakat ini di Kantor Kelurahan Balekambang, yang beralamat $\mathrm{Jl}$. Pucung No.92, RT.9/RW.2, Balekambang, Kramatjati, Kota Jakarta Timur, Daerah Khusus Ibukota Jakarta 13530.

\section{HASIL DAN PEMBAHASAN}

\section{Deskripsi Peserta Kelompok PKK Kelurahan Balekambang}

Mitra pengabdian masyarakat yang menjadi obyek dalam kegiatan pelatihan keterampilan pembuatan handycrafts dan penentuan harga jual produk dalam meningkatkan industri kreatif adalah kelompok PKK di lingkungan Kelurahan Balekambang yang merupakan lingkungan padat penduduk.

Kelompok PKK Kelurahan Balekambang yang menjadi peserta dalam kegiatan pengabdian masyarakat pelatihan keterampilan pembuatan handycrafts dan penentuan harga jual produk dalam meningkatkan industri kreatif ini dihadiri oleh 20 orang peserta anggota Kelompok PKK. Latar belakang pendidikan para peserta antara lain lulusan SD, SMP dan SMA sederajat. Jumlah rincian peserta seperti terlihat pada tabel di bawah ini : 
Tabel 5.1. Jumlah Peserta Pengabdian Masayarakat

\begin{tabular}{|c|c|c|c|}
\hline \\
\hline No & Nama & Domisili & Ket \\
\hline 1. & Pricudayati & RW 03 & Ibu RT \\
\hline 2. & Dian & RW 03 & Ibu RT \\
\hline 3. & Ida S & RW 03 & Ibu RT \\
\hline 4. & Hj. Itoh & RW 04 & Ibu RT \\
\hline 5. & Nilasari & RW 03 & Ibu RT \\
\hline 6. & Suryani & RW 03 & Ibu RT \\
\hline 7. & Suryanti & RW 04 & Ibu RT \\
\hline 8. & Zainab & RW 04 & Ibu RT \\
\hline 9. & Titi S & RW 03 & Ibu RT \\
\hline 10. & Sri uryati & RW 03 & Ibu RT \\
\hline 11. & Efie M & RW 03 & Ibu RT \\
\hline 12 & Fitri Q.A & RW 03 & Ibu RT \\
\hline 13. & Nenywati & RW 03 & Ibu RT \\
\hline 14. & Mauliana & RW 04 & Ibu RT \\
\hline 15. & Warda & RW 04 & Ibu RT \\
\hline 16. & Vina & RW 04 & Ibu RT \\
\hline 17. & Erniawati & RW04 & Ibu RT \\
\hline 18. & Nina D & RW 04 & Ibu RT \\
\hline 19. & Nisa & RW 04 & Ibu RT \\
\hline 20. & Herlina & RW 04 & Ibu RT \\
\hline
\end{tabular}

Sumber: Data Pengabdian Masyarakat (2017)

Sedangkan perincian para peserta diperlihatkan pada Tabel 5.2 berikut ini:

Tabel 5.2. Deskripsi Peserta Pengabdian Masyarakat

\begin{tabular}{|c|c|c|}
\hline No & Peserta & Jumlah \\
\hline 1. & Lulusan SD & 1 \\
\hline 2. & Lulusan SMP & 3 \\
\hline 3. & $\begin{array}{ll}\begin{array}{l}\text { Lulusan } \\
\text { sederajat }\end{array} & \text { SMA }\end{array}$ & 16 \\
\hline
\end{tabular}

Sumber : Data Pengabdian Masyarakat (2017)

Kelompok PKK memiliki anggota ibu - ibu dengan rentang usia 20 sampai dengan 65 tahun yang tersebar pada 2 RW dan 22 RT. Dalam kegiatan tersebut terdapat 3 orang anggota Karang Taruna yang turut serta dalam kegiatan tersebut. Di bawah ini dokumentasi peserta abdimas.

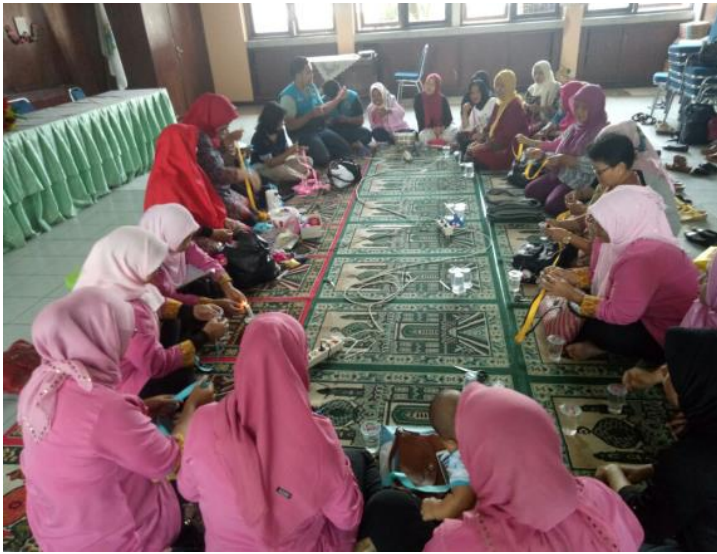

Gambar 5.1 Peserta Abdimas

\section{Hasil Pengabdian Masyarakat}

Berdasarkan pelaksanaan pengabdian masyarakat yang dilaksanakan, terdapat beberapa kendala yang ditemui diantaranya tidak semua ibu-ibu kelompok PKK memiliki kreativitas dan jiwa berinovasi dan agak kesulitan dalam memahami proses perhitungan penentuan harga jual. Hal tersebut dikarenakan tingkat pendidikan dan faktor usia dari peserta yang beragam.

Berikut adalah perhitungan penentuan harga jual produk :

Harga jual $=$ biaya + margin keuntungan

\begin{tabular}{|c|c|}
\hline Jenis & Biaya $(\mathbf{R p})$ \\
\hline Renda & 5.000 \\
\hline Ros mekar satin & 5.000 \\
\hline Ros kuncup satin & 2.000 \\
\hline kain flanel & 500 \\
\hline Mote & 1.000 \\
\hline Peniti untuk bros & 1.000 \\
\hline Lem & 1.000 \\
\hline Benang + Jarum & 1.000 \\
\hline Kemasan & 1.000 \\
\hline Label & 500 \\
\hline Jasa pembuatan/pcs & 1.500 \\
\hline $\begin{array}{l}\text { Jumlah biaya } \\
\text { produksi }\end{array}$ & 19.500 \\
\hline $\begin{array}{l}\text { Laba } 30 \% \text { (dari biaya } \\
\text { produksi }\end{array}$ & 5.850 \\
\hline Total (harga / pcs ) & 25.350 \\
\hline
\end{tabular}


2. Harga Jual Headband/ Bando

\begin{tabular}{lr}
\hline \multicolumn{1}{c}{ Jenis } & Biaya (Rp) \\
\hline $\begin{array}{l}\text { Bando/headband } \\
\text { polos }\end{array}$ & 3.000 \\
\hline Fower ribbon & 4.000 \\
\hline Pita satin & 2.000 \\
\hline Pita emas & 2.000 \\
\hline Manik-manik/mote & 1.000 \\
\hline Lem & 1.000 \\
\hline Kemasan & 1.000 \\
\hline Label & 500 \\
\hline Jenis & 1.500 \\
\hline Jasa pembuatan / pcs & $\mathbf{1 6 . 0 0 0}$ \\
\hline $\begin{array}{l}\text { Jumlah biaya } \\
\text { produksi }\end{array}$ & 4.000 \\
\hline $\begin{array}{l}\text { Laba 25 \% (dari } \\
\text { biaya produksi }\end{array}$ & $\mathbf{2 0 . 0 0 0}$ \\
\hline Total (harga / pcs ) & \\
\hline
\end{tabular}

3. Harga Jual Jepit Rambut

\begin{tabular}{lr}
\hline \multicolumn{1}{c}{ JENIS } & \multicolumn{1}{c}{ BIAYA } \\
(Rp)
\end{tabular}

\section{Manfaat Abdimas Bagi Kelompok Ibu - Ibu PKK Kel. Balekambang}

Kegiatan pengabdian masyarakat ini memberikan nilai positif atas keaktifan Ibu - Ibu PKK Kelurahan Balekambang. Tidak semua kelompok PKK dikelola oleh ibu - ibu yang aktif. Terdapat pula kelompok PKK yang sebagian besar anggotanya pasif beraktivitas. Keaktifan kelompok Ibu - Ibu
PKK menjadi tambahan nilai bagi Kinerja Kelurahan yang dianggap telah berhasil membina kader PKK di lingkungan Kelurahan Balekambang untuk menjadi ibu - ibu yang aktif yang dapat memberikan manfaat bagi masyarakat.

Karena kehadiran pengabdian masyarakat ini dianggap sangat membawa manfaat bagi Kelurahan Balekambang, sehingga ketua dari Kelompok PKK meminta tim abdimas untuk menjalin kerjasama secara berkala dengan kelompok RW yang berbeda dan jenis pelatihan yang berbeda yang dapat menambah pengetahuan dan kreativitas Kelompok PKK di Kelurahan Balekambang.

\section{SIMPULAN}

Untuk memberikan pelatihan pembuatan handycraft dan perhitungan penentuan harga jual, tidak mudah. Hal tersebut dikarenakan tingkat pendidikan dan usia yang beragam. Sehingga pelatihan sangat jauh dari target yang ditetapkan tim. Walaupun antusiasme peserta sangat tinggi, namun hal tersebut tidak dibarengi dengan keterampilan dan kemampuan peserta.

Peserta abdimas pelatihan adalah ibu - ibu yang memang aktif dalam kegiatan di Kelurahan Balekambang. Tidak sedikit dari mereka yang memang sudah biasa membuat kerajinan tangan dan usaha kuliner. Namun kerajinan yang dibuat hanya kerajinan sederhana yang hanya menempel flanel pada wadah barang bekas.

Dengan kegiatan abdimas ini tim berharap dapat menghasilkan panduan bagi ibu - ibu PKK untuk menjadi wiraswasta pemula. Kegiatan pengabdian masyarakat secara umum bermanfaat bagi peningkatan kinerja kelompok Ibu - Ibu PKK yang 
selanjutnya membawa nilai positif bagi kinerja Kelurahan Balekambang.

\section{DAFTAR PUSTAKA}

Buku :

Anggraini, N., (2008). Industri Kreatif, Jurnal ekonomi Desember 2008 Volume XIII No. 3 hal. 144-151

Benson, J., \& Zhu, Y., (2005). Unemployment In Asia. First Publish. London and New York : Routledge.

Mulyadi. (2014). Akuntansi Biaya Edisi ke -5. Yogyakarta : STIE YKPN

Mulyadi. (1997). Akuntansi Manajemen : Konsep, Manfaat, Dan Rekayasa. Edisi ke - 2. Yogyakarta : STIE YKPN

Sukirno,S. (2004). Makro Ekonomi. Edisi Ketiga. Jakarta: PT. Raja Grafindo Persada

Suryana. (2003). Kewirausahaan. Pedoman praktis, kiat dan proses menuju sukses. Jakarta : PT Salemba Empat

\section{Internet :}

Badan Pusat Statistik. Konsep/ Penjelasan Teknis. Diakses dari : https://www.bps.go.id/subjek/vie w/id/6 pada 23 September 2017.

Faizal, A. (2012). Kemenakertrans: Industri Kreatif Atasi Pengangguran. Diakses dari : http://ekonomi.kompas.com/read/ 2012/10/13/02052851/Kemenaker trans.Industri.Kreatif.Atasi.Penga ngguran pada 23 September 2017.

Jefriando, M. (2017). Jumlah Pengangguran di RI Capai 7,01 Juta Orang, Turun Tipis. (Online) Diakses dari

https://finance.detik.com/beritaekonomi-bisnis/3492635/jumlahpengangguran-di-ri-capai-701juta-orang-turun-tipis. pada 23 September 2017.

World Bank. (2017). Publication : Laporan Triwulanan Perekonomian Indonesia Maret 2017: Melanjutkan Perbaikan. Diakses dari http://www.worldbank.org/in/cou ntry/indonesia/publication/indone sia-economic-quarterly-march2017 pada 23 September 2017 